\title{
KERUPUK IKAN LELE (Clarias Sp) DENGAN SUBTITUSI TEPUNG TALAS (Colocasia esculental L. Schoott)
}

\author{
(Crackers of Snakehead Fish (Clarias sp) With Subtitution of Taro Flour \\ (Colocasia esculental L. Schoott).
}

\section{Adnan Engelen dan Ika Okhtora Angelia}

\author{
Politeknik Gorontalo \\ Program Studi Teknologi Hasil Pertanian, Kampus Politeknik Gorontalo, Gorontalo \\ Jl. Muchlis Rahim, Desa Panggulo Barat, Kecamatan Botupingge, \\ Kabupaten Bone Bolango, Provinsi Gorontalo \\ Email: adnanengelen@poligon.ac.id
}

\begin{abstract}
ABSTRAK
Kerupuk merupakan salah satu jenis makanan kering yang terbuat dari bahan-bahan yang mengandung pati cukup tinggi dan merupakan jenis makanan kecil yang mengalami pengembangan volume dan mempunyai densitas rendah selama proses penggorengan. Tujuan penelitian adalah untuk menentukan komposisi terbaik antara daging ikan lele dengan tepung talas dalam pembuatan kerupuk dan menentukan kandungan fisik dan kimia. Uji yang dilakukan pada penelitian ini adalah uji kadar air, kadar abu, uji kemekaran, dan uji organoleptik. Pada perhitungan ini menggunakan perbandiangan daging ikan lele, tepung talas dan tapioka, dengan 3 perlakuan yaitu A1 (100 g ikan lele : $0 \mathrm{~g}$ tepung talas : $300 \mathrm{~g}$ tapioka), A2 (75 g ikan lele : $25 \mathrm{~g}$ tepung talas : $300 \mathrm{~g}$ tapioka), A3 (50 g ikan lele : $50 \mathrm{~g}$ tepung talas : $300 \mathrm{~g}$ tapioka). Hasil penelitian menunjukan bahwa perlakuan yang paling disukai oleh panelis adalah perlakuan A1. Perlakuan pada pembuatan kerupuk ikan lele dengan subtitusi tepung talas memiliki nilai rata-rata kadar air dan kadar abu adalah 3.29\% dan 1.72\%. Uji kemekaran pada perlakuan A1 memiliki tingkat kemekaran paling tinggi $(328,31)$ dibandingkan pada perlakuan A2 dan A3.
\end{abstract}

Kata kunci : Ikan lele; kerupuk; tepung talas

\section{ABSTRACT}

Crackers is one type of dry food made from ingredients that contain high starch and is a type of snack that experienced volume development and has a low density during the frying process. The objective of the study was to determine the best composition between snakehead fish meat with taro flour in making crackers and to determine the physical and chemical content. The test conducted in this research was water content, ash content, bloom test, and organoleptic tests. In this calculation using the bait of snakehead fish, taro and tapioca flour, with 3 treatments that was A1 (snakehead fish of $100 \mathrm{~g}$ : taro flour of $0 \mathrm{~g}$ : tapioca of $300 \mathrm{~g}$ ), A2 (snakehead fish of 75 $\mathrm{g}$ : taro flour of $25 \mathrm{~g}$ : tapioca of $300 \mathrm{~g}$ ), A3 (snakehead fish of $50 \mathrm{~g}$ : taro flour of $50 \mathrm{~g}$ : tapioca of $300 \mathrm{~g}$ ). The results showed that the most preferred treatment by panelists was treatment of A1. Treatment on snakehead fish cracker manufacturing with substitution of taro flour had the average value of water content and ash content was 3.29\% and $1.72 \%$ respectively. The blooming test at treatment of A1 had the highest bloom rate (328.31) compared to $\mathrm{A} 2$ and $\mathrm{A} 3$ treatments.

Keywords: Snakehead fish; crackers; taro flour

\section{PENDAHULUAN}

Indonesia memiliki perairan tawar yang sangat luas dan berpotensi besar untuk usaha budidaya ikan lele. Sumberdaya perairan Indonesia meliputi perairan umum (sungai, waduk dan rawa), sawah (mina padi), dan kolam dengan total luas lahan 605,990 hektar. Dengan potensi perairan tawar yang sangat besar tersebut, Indonesia baru mampu memproduksi 6,7 juta ton ikan/tahun. Hal ini tentu saja masih jauh di bawah produksi dunia yang mencapai 100 juta ton ikan per tahun (Ade, 1994).

Ketersediaan sumberdaya perairan yang luas dan sumber daya manusia merupakan modal dasar untuk meningkatkan dan mengembangkan produksi ikan lele di Indonesia dan sampai tahun 2010 produksi ikan lele mencapai 242,811 ton. Ikan 
lele memiliki keunggulan dibandingkan dengan produk hewan lainnya karena ikan lele kaya akan leusin dan lisin. Leusin $\left(\mathrm{C}_{6} \mathrm{H}_{13} \mathrm{NO}_{2}\right)$ berguna untuk perombakan dan protein otot. Sedangkan lisin merupakan salah satu dari 9 asam amino esensial yang dibutuhkan untuk pertumbuhan dan perbaikan jaringan. Lisin termasuk asam amino yang sangat penting dan dibutuhkan dalam pertumbuhan dan perkembangan anak (Zaki, 2009). Salah satu cara untuk memanfaatkan daging ikan lele adalah dengan mengolahnya menjadi produk olahan pangan yang di sukai masyarakat misalnya naget ikan lele, abon ikan lele maupun kerupuk ikan lele.

Talas (Colocasia esculenta L) merupakan salah satu tanaman pangan jenis herba menahun. Talas memiliki nama umum di dunia yaitu, Taro, Old cocoyam, Abalong, Taioba, Arvi, Keladi, Satoimo, Tayoba dan Yutao. Tanaman talas memiliki banyak fungsi sebagai penghasil karbohidrat bagi bahan pangan dan bahan baku industri serta dapat digunakan untuk pakan ternak (Yuliatmoko dan Satyatama, 2012). Nilai ekonomi tanaman talas tinggi karena hampir sebagian besar bagian tanaman dapat dimanfaatkan untuk dikonsumsi manusia. Talas merupakan tanaman yang mudah dibudidayakan sehingga memiliki potensi yang besar untuk dikembangkan.

Zat gizi dalam umbi talas cukup tinggi sehingga memiliki beberapa manfaat seperti melancarkan pencernaan, menstabilkan peredaran darah, dan masih banyak lagi. Adapun manfaat umbi talas adalah sebagai bahan pangan sumber karbohitrat (Hartati dan Prana 2003). Bagian tanaman ini yang dapat dimakan yaitu umbi, tunas muda, dan batang daun. Selain itu umbi dan pelepah dan daun talas dapat dimanfaatkan sebagai bahan pangan obat, maupun pembungkus makanan, sedangkan daun kulit dan ampas umbinya dapat dimanfaat sebagai makanan ternak. Selai dapat digunakan sebagai bahan pangan talas juga digunakan untuk minuman. Akar rimpangnya jika difermentasikan dan ditambah gula serta semacam jagung (kaffir corn) dan air akan menjadi sejenis bir. Penambahan tepung talas pada pembuatan kerupuk ikan lele diharapkan mampu menambah nilai gizi dan mutu dari kerupuk ikan lele.

Pembuatan kerupuk ikan lele ini mengunakan bahan dasar ikan lele dan tepung tapioka serba bumbu-bumbu tambahan lainnya. Penggunan tepung talas pada pembuatan kerupuk ikan lele dimaksudkan untuk menghasilkan kerupuk yang memiliki tingkat kemekaran yang baik karena tepung talas memiliki zat gizi yang banyak dan baik untuk kebutuhan gizi manusia. Tepung talas juga memiliki harga lebih murah dibandingkan harga terigu. Oleh sebab itu penelitian ini dilakukan dengan menambahkan tepung talas dalam pembuatan kerupuk.

\section{METODE PENELITIAN}

\subsection{Alat dan Bahan}

Alat yang digunakan dalam pembuatan kerupuk dari ikan lele dengan subtitusi tepung talas : timbangan, wadah, panci, kompor, pengaduk, penyaring, blender, pisau, talenan, sendok dan oven. Alat analisis oven, cawan, timbangan, labu takar, pipet, desikator, erlenmeyer, destilasi, labu kjeldahl, labu destilasi, pipet volume.

Bahan yang digunakan dalam pembuatan kerupuk dari ikan lele dengan subtitusi tepung talas : ikan lele, talas, tepung tapioka, garam, air, pewarna. Bahan analisis aquades, $\mathrm{H}_{2} \mathrm{SO}_{4}$, NHCI, asam borat, indikator, selenium, batu didih.

\subsection{Prosedur Kerja}

1. Campuran ikan lele dan tepung talas sesuai perlakuan :

2. $\mathrm{A} 1=$ Ikan lele $100 \mathrm{~g}: 0 \mathrm{~g}$ tepung talas: $300 \mathrm{~g}$ tepung tapioka

3. A2 $=$ Ikan lele $75 \mathrm{~g}: 25 \mathrm{~g}$ tepung talas: $300 \mathrm{~g}$ tepung tapioka 
4. A3 $=$ Ikan lele $50 \mathrm{~g}: 50 \mathrm{~g}$ tepung talas: $300 \mathrm{~g}$ tepung tapioka

5. Pembuatan adonan kerupuk

6. Pencetakan adonan kerupuk dan pengukusan

7. Pendinginan dan Pengerasan

8. Pengirisan

9. Pengeringan dan Pengemasan

10. Penggorengan

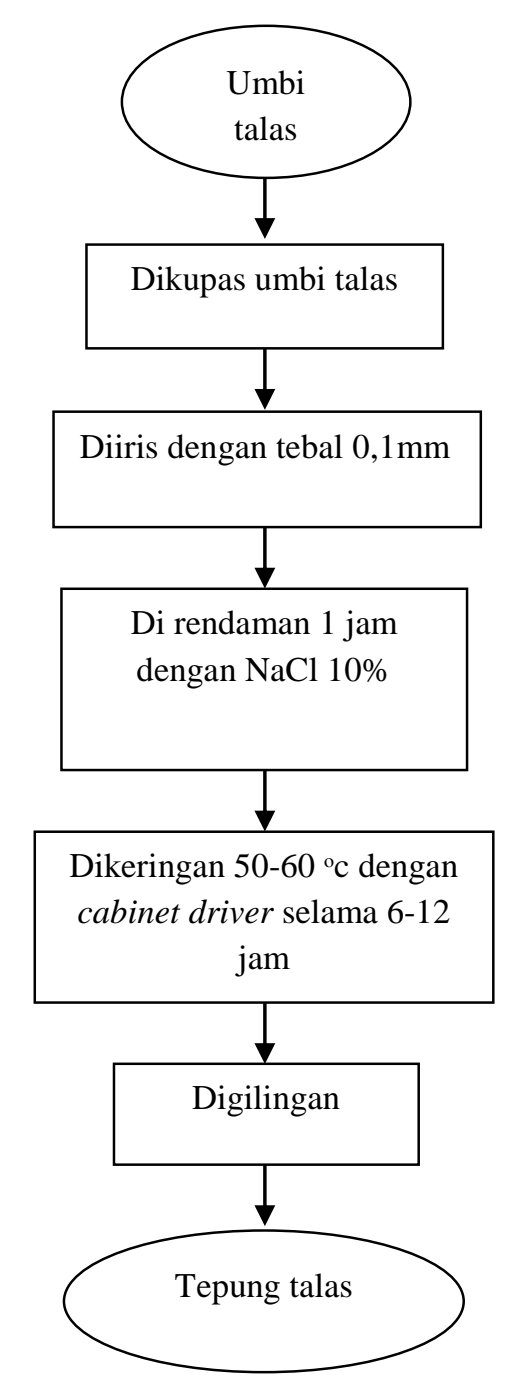

Gambar 1. Diagram alir pembuatan tepung talas

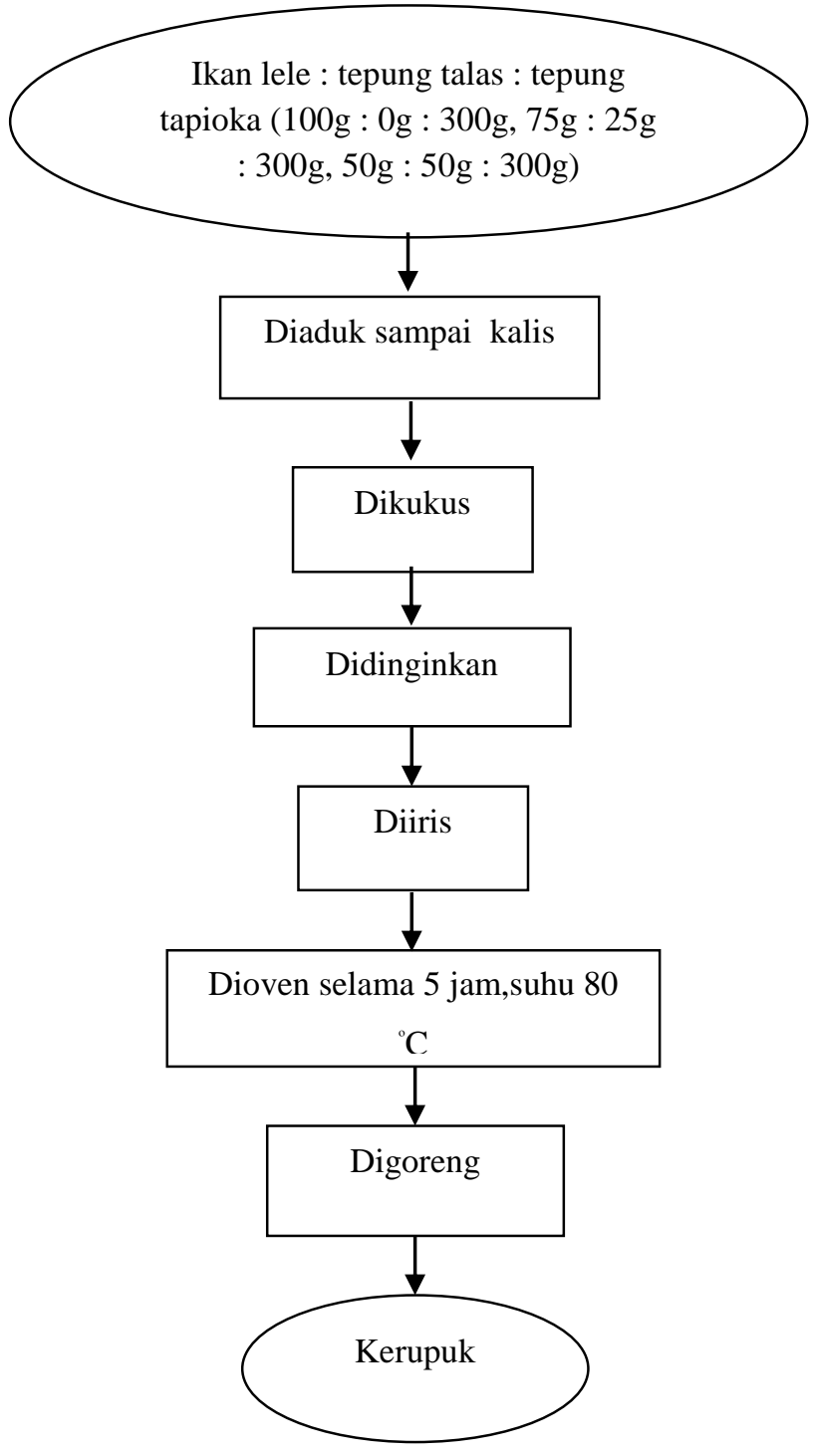

Gambar 2. Diagram alir pembuatan kerupuk ikan lele. Modifikasi Tababaka (2004)

\subsection{Analisis Data (Andarwulan dkk., 2011)}

Pada penelitian ini menggunakan perbandingan antara daging ikan lele dan tepung talas dengan perlakuan:

$\mathrm{A} 1=$ Ikan lele $100 \mathrm{~g}: 0 \mathrm{~g}$ tepung talas :

$300 \mathrm{~g}$ tepung tapioka

A2 = Ikan lele $75 \mathrm{~g}: 25 \mathrm{~g}$ tepung talas :

$300 \mathrm{~g}$ tepung tapioka

A3 = Ikan lele $50 \mathrm{~g}: 50 \mathrm{~g}$ tepung talas :

$300 \mathrm{~g}$ tepung tapioca

Setiap perlakuan dilakukan tiga kali ulangan, sehingga secara keseluruhan jumlah 
sampel yang diamati sebanyak 9 sampel. Metode yang digunakan untuk mengolah data yaitu metode RAL (Rancangan Acak Lengkap). Data yang dihasilkan kemudian diolah menggunakan uji analisis sidik ragam untuk melihat pengaruh perlakuan

\subsection{Jenis Dan Sumber Data (Andarwulan dkk.,2011)}

Penulisan tugas akhir ini dilakukan dengan menelusuri pustaka literatur yang berhubungan dengan penulisan proposal tugas akhir yang berupa data primer dan sekunder. Sumber data sekunder berupa jurnal sedangkan primer berasal dari hasil pengujian organoleptik dan analisis sifat kimia kerupuk ikan lele dengan penambahan tepung talas.

\subsection{Parameter yang Diamati}

Parameter yang akan diamati, yaitu uji organoleptik yang meliputi rasa, aroma, warna, dan tekstur, sedangkan analisis kimia berupa, kadar air, kadar abu, kemekaran.

\section{a. Organoleptik}

Organoleptik merupakan pengujian terhadap bahan makanan berdasarkan kesukaan dan kemauan untuk mempergunakan suatu produk. Uji Organoleptik atau uji indera atau uji sensoris sendiri merupakan cara pengujian dengan menggunakan indera manusia sebagai alat utama untuk pengukuran daya peneriman terhadap produk.

Uji organoleptik ini dilakukan dengan menggunakaan metode hedonik pada 30 orang panelis. Parameter yang akan diuji meliputi rasa, aroma, tekstur, dan warna.

Para panelis disajikan sampel satu persatu, kemudian panelis diminta menilai sampel tersebut berdasarkan tingkat kesukaan terhadap rasa, aroma, dan tekstur sampel. Dengan memberikan standar nilai yang telah tersedia. Adapun skala nilai yang digunakan adalah sangat suka (skor 5), suka (skor 4), sedang (skor 3), tidak suka (skor 2), sangat tidak suka (skor 1).

\section{b. Kadar Air (Andarwulan dkk., 2011)}

Cawan kosong dikeringkan dalam oven selama 15 menit dan didinginkan dalam desikator, kemudian timbang sekitar 5 gram sample yang sudah dihomogenkan dalam cawan. Tempatkan cawan beserta isi di dalam oven pada suhu $100-102{ }^{\circ} \mathrm{C}$ selama 6 jam. Hilangkan kontak antara cawan dengan dinding oven. Pindahkan cawan ke desikator, lalu dinginkan. Setelah dingin timbang kembali. Keringkan kembali didalam oven (dilakukan pengulangan beberapa kali dengan waktu dari setiap pengeringan adalah 1 jam) sampai memperolah bobot yang tetap.

Kadar air dalam bahan dihitung dengan rumus berikut :

$$
\% \text { kadar air }=\frac{\mathrm{b}-(\mathrm{c}-\mathrm{a})}{\mathrm{b}} \times 100 \%
$$

Keterangan :

$\mathrm{a}=$ berat cawan kering yang sudah konstan

$\mathrm{b}=$ berat sampel awal

$\mathrm{c}=$ berat cawan dan sampel kering yang sudah konstan

\section{c. Kadar Abu (Andarwulan dkk., 2011)}

Sebanyak 5-10 g sampel ditimbang di dalam cawan, kemudian dimasukkan ke dalam tanur dan dipanaskan p ada suhu $300{ }^{\circ} \mathrm{C}$, kemudian suhu dinaikkan menjadi $420-550{ }^{\circ} \mathrm{C}$ dengan waktu sesuai karakteristik bahan (umumnya 5-7 jam). Jika diperkirakan semua karbon belum teroksidasi, cawan diambil dari dalam tanur, lalu didinginkan ke dalam desikator dapat ditambahkan 1-2 mL $\mathrm{HNO}_{3}$ pekat. Sampel diuapkan sampai kering dan dimasukkan kembali ke dalam tanur sampai pengabuan dianggap selesai. Selanjutnya tanur dimatikan dan dapat dibuka setelah suhunya mencapai $250{ }^{\circ} \mathrm{C}$ atau kurang. Cawan diambil dengan hati-hati dari dalam tanur kemudian ditimbang.

Kadarabu dalam sampel dapat dihitung dengan rumus sebagai berikut:

$$
\% \text { kadar } \mathrm{abu}=\frac{\mathrm{W}_{2-} \mathrm{W}_{0}}{\mathrm{~W}_{1-} \mathrm{W}_{0}} \times 100 \%
$$


Keterangan :

$$
\begin{aligned}
\mathrm{W}_{2}= & \text { Berat cawan }+ \text { sampel setelah } \\
& \text { pengabuan }(\mathrm{g}) \\
\mathrm{W}_{0}= & \text { Berat cawan kosong }(\mathrm{g}) \\
\mathrm{W}_{1}= & \text { Berat cawan }+ \text { sampel sebelum } \\
& \text { pengabuan }(\mathrm{g})
\end{aligned}
$$

d. Uji Kemekaran (Koesbandi, 1974)

Kemekaran Kerupuk ditetapkan dengan melihat perubahan luasan kerupuk sebelum dan sesudah di goring, pengukuran panjang dan lebar irisan kerupuk menggunakan jangka sorong. Persentase kemekarana dihitung dengan rumus :

$$
\text { Kemekaran }(\%)=\frac{\mathrm{Li}}{\mathrm{Lo}} \times 100 \%
$$

Keterangan:

Lo $=$ Luas kerupuk mentah (panjang $\mathrm{x}$ lebar)

$\mathrm{Ll}=$ Luas kerupuk matang (panjang $\mathrm{x}$ lebar)

\section{HASIL DAN PEMBAHASAN}

\subsection{Organolaptik}

Organoleptik merupakan pengujian terhadap bahan makanan berdasarkan kesukaan terhadap suatu produk. Uji Organoleptik atau uji sensoris merupakan cara pengujian dengan menggunakan indera manusia sebagai alat utama untuk pengukuran daya peneriman terhadap produk.

Uji organoleptik ini dilakukan dengan menggunakaan metode hedonik pada beberapa orang panelis. Parameter yang akan diuji meliputi : rasa, aroma, tekstur dan warna. Para panelis disajikan sampel satu persatu, kemudian panelis diminta menilai sampel tersebut berdasarkan tingkat kesukaan terhadap rasa, aroma, dan tekstur sampel.

\subsubsection{Rasa}

Menurut Winarno, (2008) rasa adalah penilaian yang menggunakan indra pengecap atau lidah. Rasa juga merupakan salah satu faktor mutu yang dapat mempengaruhi suatu prodak pangan.
Penginderaan cicipan atau rasa dibagi menjadi empat cicipan utama yaitu asin, asam, manis, pahit.

Hasil uji organoleptik terhadap paramerer rasa kerupuk ikan lele dengan subtitusi tepung talas ketiga perlakuan dapat di lihat pada Gambar 3 di bawah ini

\begin{tabular}{|r|r|r|}
3.9 \\
3.85 \\
3.8
\end{tabular}

Gambar 3. Hasil organoleptik rasa kerupuk ikan lele subtitusi tepung talas

Berdasarkan hasil organoleptik terhadap rasa kerupuk ikan lele dengan subtitusi tepung talas bahwa tingkat penerima panelis terhadap parameter rasa kerupuk ikan lele dengan subtitusi tepung talas lebih pada perlakuan A1 sebesar 3.87 semtara perlakuan A2 sebesar 3.77 dan perlakuan A3 sebesar 3.63. Dari ketiga hasil panelis nilai yang diberikan terhadap ketiga perlakuan kerupuk ikan lele dengan subtitusi tepung talas tingkat suka sampai netral/biasa.

Hasil uji organoleptik terhadap rasa kerupuk ikan lele dengan subtitusi tepung talas menujukan bahwa perlakuan A1 yang paling disukai lalu perlakuan A2 sedangkan perlakuan A3 tidak begitu banyak yang meminatinya/menyukai karena adanya penambahan komposisi tepung talas pada perlakuan A2 dan A3 Winarno (2008). 


\subsubsection{Aroma}

Menurut Winarno (2008) aroma makanan umumnya menentukan kelezatan bahan makanan dan banyak berhubungan dengan indra penciuman. Senyawa beraroma sampai ke jaringan pembau dalam hidung, bersama-sama dengan udara. Pada umumnya aroma diterima oleh otak lebih banyak merupakan berbagai ramuan atau campuran empat aroma utama yaitu, harum, asam, tengik, dan hagus. Hasil uji organoleptik terhadap parameter aroma dapat dilihat pada Gambar 4

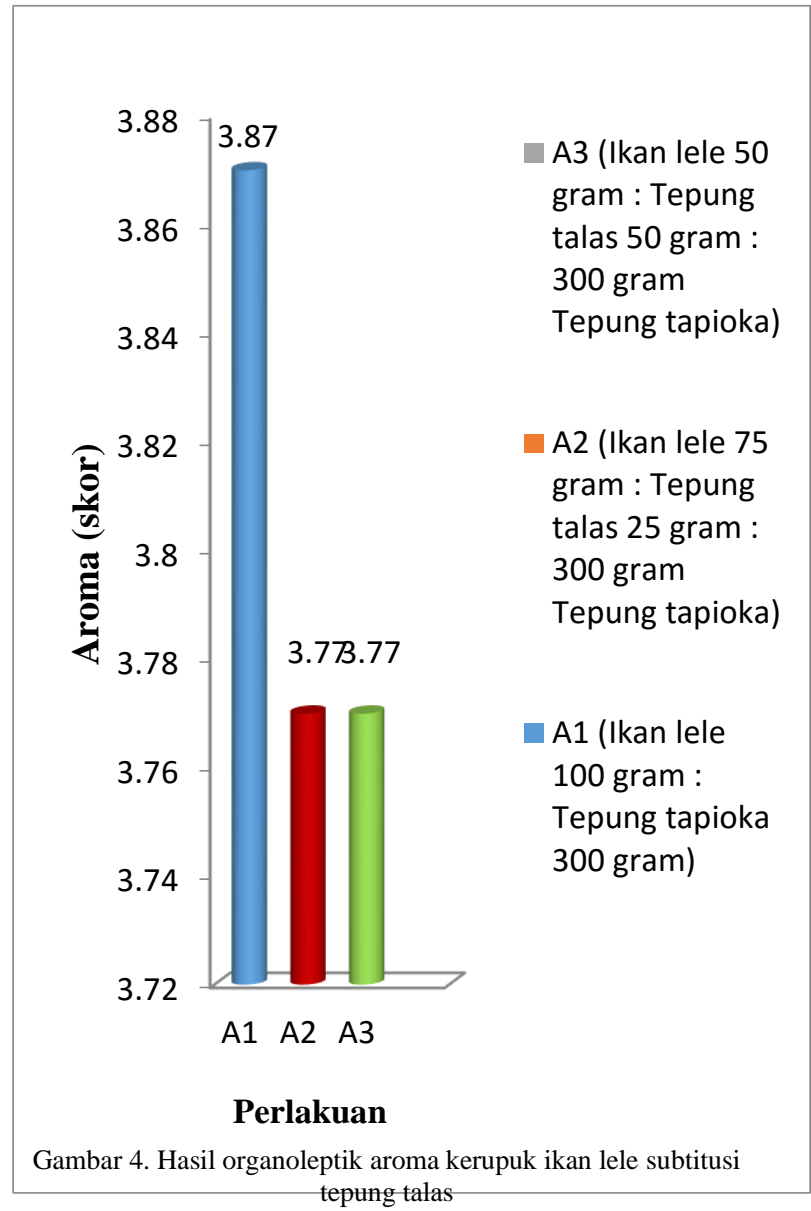

Berdasarkan hasil uji organoleptik aroma kerupuk ikan lele dengan subtitusi tepung talas tingkat penerimaan panalis terhadap parameter aroma kerupuk ikan lele dengan subtitusi tepung talas pada perlakuan A1 (ikan lele,,tapioka: 100 : 300) sedangkan pada parameter A2 (ikan lele, tepung talas, tapioka: $75: 25: 300$ ) dan A3 (ikan lele, tepung talas, tapioka : $50: 50: 300)$ rata/netral. Tingkat kesukaan panelis terhadap A1 sebesar 3.87 sementara perlakuan A2 dan A3 sama tingkat kesukaan pannelisnya sebesar 3.77 rata-rata/netral.

Hasil uji organoleptik terhadap aroma kerupuk ikan lele dengan subtitusi tepung talas menunjukan bahwa dari 3 perlakuan yang panelis lebih menyukai A1 3.87, hal ini karena perlakuan A1 memiliki aroma ikan lele yang cukup menyengat. Sedangkan perlakuan A2 dan A3 samasama tingkat kesukaan panelisnya karena perpaduan ikan lele dan tepung talasnya.

\subsubsection{Tekstur}

Menurut (Kartika dkk, 1998) tekstur merupakan sensasi tekanan yang dapat diamati dengan mulut (pada waktu digigit, dikunyah dan ditelan) adapun perubahan dengan jari. Setiap bentuk makanan mempunyai sifat tekstur tersendiri tergantung pada keadaan fisik dan ukuran, penilaian tekstur dapat berupa kekerasan elastisitas ataupun kerenyahan. Tekstur prodak pangan merupakan salah satu komponen yang dinilai dalam uji organoleptik.

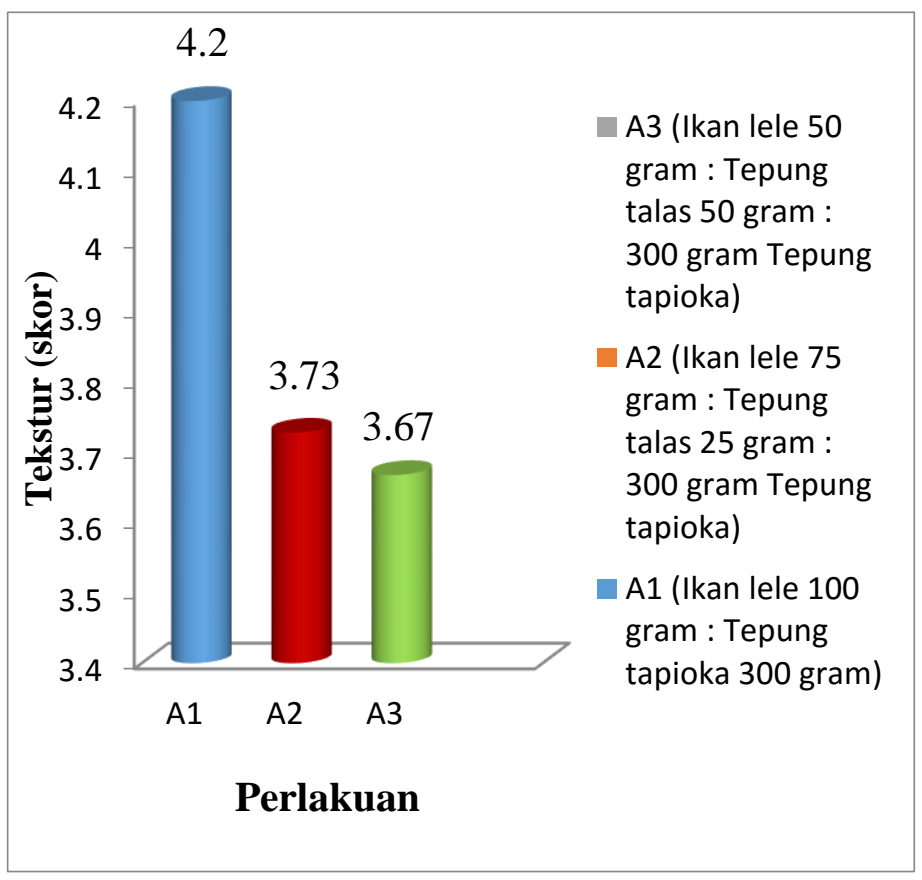

Gambar 5. hasil uji organoleptik tekstur kerupuk ikan lele subtitusi tepung talas. 
Berdasarkan hasil uji organoleptik terhadap tekstur kerupuk ikan lele denga subtitusi tepung talas menujukan bahwa peneriman panelis terhadap parameter tekstur kerupuk ikan lele dengan subtitusi tepung talas perlakuan A1 lebih besar dari pada perlakuan A2 dan A3. Hasil uji organoleptik menujukan kerupuk ikan lele dengan subtitusi tepung talas panelis lebih menyukai tekstur pada perlakuan A1 (4.2) sedangkan perlakuan A2 (3.73) dan A3 (3.63).

\subsubsection{Warna}

Menurut Winarno (2008) secara visual faktor tampilan lebih dahulu dan kadang- kadang sangat menentukan dalam penerimaan konsumen. Warna juga merupakan salah satu parameter yang digunakan konsumen dalam memilih produk. Nilai sensori tingkat kesukaan warna dari kerupuk ikan lele dengan subtitusi tepung talas pada Gambar 6 berikut.

Berdasarkan hasil uji organoleptik terhadap warna kerupuk ikan lele dengan subtitusi tepung talas menunjukan bahwa tingkat penerimaan panelis terhadap parameter warna kerupuk ikan lele dengan sutitusi tepung talas pada perlakuan A1 lebih tinggi dibandingkan dengan perlakuan A2, begitu juga perlakuan A1 lebih disukai panelis dari pada A3. Tingkat kesukaan panelis terhadap perlakuan A1 sebesar 4.63 sementara pada perlakuan A2 3.87 dan A3 3.67. Nilai yang diberikan para panelis terhadap ketiga perlakuan biskuit ikan lele pada tingkat suka sampai netral.

Hasil uji organoleptik terhadap warna kerupuk ikan lele dengan suptitusi tepung talas menujukan bahwa tiga perlakuan yang dilakuan panelis berpendapat secara keseluruhan bahwa warna yang dihasilkan oleh ketiga perlakuan dalam taraf biasa/netral sampai suka. Dari semua perlakuan panelis lebih menyukai warna kerupuk ikan lele dengan subtitusi tepung talas pada perlakuan A1, karena pada perlakuan ini penambahan tepung

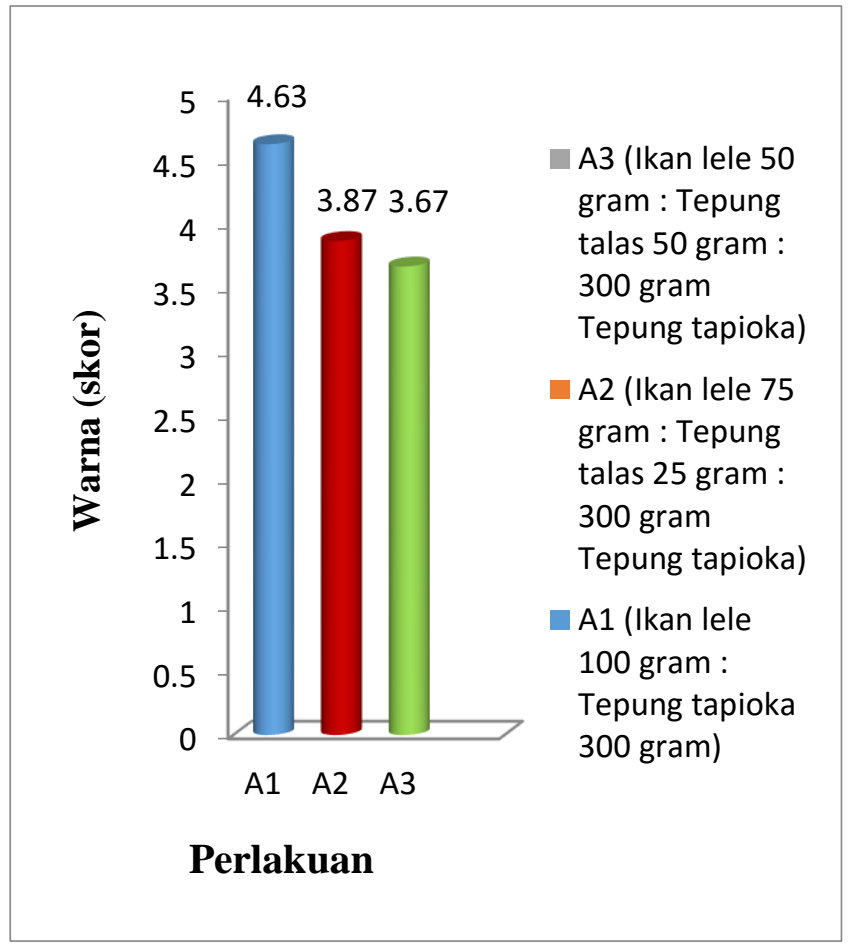

Gambar 6. Hasil organoleptik warna kerupuk ikan lele subtitusi tepung talas

tapioka lebih banyak dibandingkan dengan perlakuan lainnya sehingga warna yang dihasilkan pada perlakuan lebih warna putih (Winarno, 2002)

\subsubsection{Kadar Air}

Hasil analisis rata-rata kadar air pada kerupuk ikan lele dengan subtitusi tepung talas dengan tiga kali pengulangan analisa dengan hasil ditunjukan oleh Tabel 1 dan Gambar 7 di bawah ini.

\begin{tabular}{cc}
\hline Perlakuan & Rata-rata $(\%)$ \\
\hline A1 & 3,29 \\
A2 & 3,98 \\
A3 & 4,21 \\
\hline
\end{tabular}

Tabel 1. Nilai rata-rata kadar air kerupuk ikan lele dengan subtitusi tepung talas 


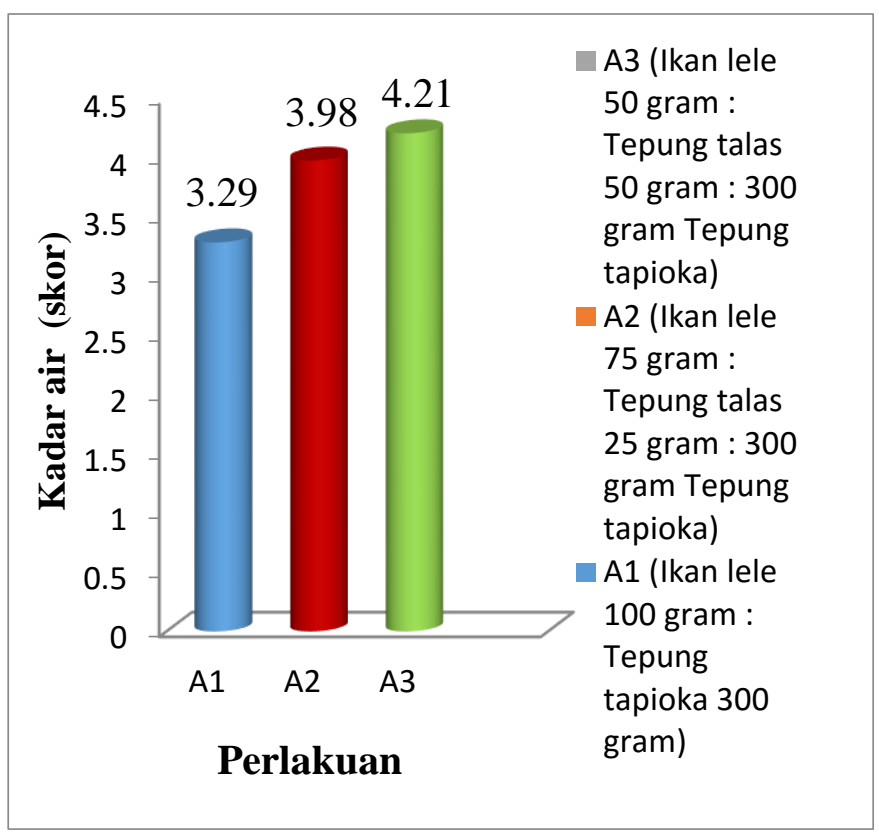

Gambar 7. Nilai rata-rata kadar air kerupuk ikan lele dengan subtitusi tepung talas

Berdasarkan Gambar 7 di atas, nilai ratarata kadar air pada kerupuk ikan lele dengan subtitusi tepung talas $\mathrm{F}_{\text {hitung }}$ (2.68) lebih kecil dari $\mathrm{F}$ tabel $(0.05)$ yaitu (5.14) dan $\mathrm{F}_{\text {tabel }}(0.01)$ yaitu 10.92 . Hasil analisis sidik ragam ini menunjukan bahwa kerupuk ikan lele dengan subtitusi tepung talas tidak berpengaruh

Dilihat dari tabel 1 di atas, nilai rata-rata kadar air yang terbaik dimiliki oleh perlakuan A3 yaitu $4.21 \%$, semakin rendah kadar air maka semakin baik produk tersebut, sedangkan nilai ratarata kadar air yang tertinggi dimiliki oleh perlakuan A1 yaitu 3.29\%. Hal ini disebabkan semakin banyak penambahan tepung talas pada kerupuk pada setiap perlakuan akan berpengaruh pada nilai rata-rata kadar air yang diperoleh.

\subsubsection{Kadar Abu}

Hasil analisis rata-rata kadar abu pada kerupuk ikan lele pada subtitusi tepung talas dengan tiga kali pengulangan analisa dengan hasil ditunjukan oleh tabel 2 dan gambar 8 di bawah ini.

\begin{tabular}{cc}
\hline Perlakuan & Rata-rata $(\%)$ \\
\hline A1 & $1,72^{\mathrm{a}}$ \\
A2 & $2,20^{\mathrm{b}}$ \\
A3 & $2,54^{\mathrm{c}}$ \\
\hline
\end{tabular}

Tabel 2. Nilai rata-rata kadar abu pada kerupuk ikan lele dengan subtitusi tepung talas

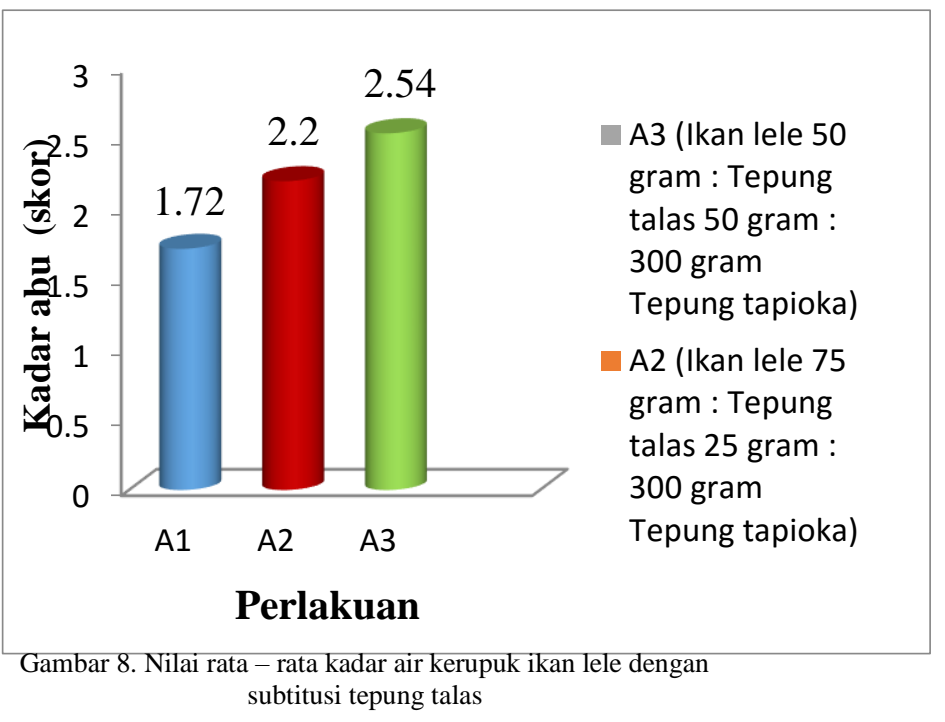

Berdasarkan Gambar 10 di atas, nilai ratarata kadar abu pada kerupuk ikan lele dengan subtitusi tepung talas $\mathrm{F}$ hitung (696.683) lebih besar dari $F_{\text {tabel }}(0.05)$ yaitu (5.14) dan $F_{\text {tabel }}(0.01)$ yaitu 10.92. Hasil analisis sidik ragam ini menunjukan bahwa kerupuk ikan lele dengan subtitusi tepung talas berbeda nyata terhadap kadar abu pada ketiga perlakuan tersebut, sehingga dilakukan uji BNT lagi.

Dilihat dari tabel 2 di atas, nilai rata-rata kadar abu terendah dimiliki oleh perlakuan A3 yaitu $2.54 \%$, semakin rendah kadar air maka semakin baik produk tersebut, sedangkan nilai rata-rata kadar air yang tertinggi dimiliki oleh perlakuan A1 yaitu 1.72\%. Hal ini disebabkan semakin banyak penambahan tepung talas pada setiap perlakuan akan berpengaruh pada nilai rata-rata. Hal ini kandungan abu kerupuk ikan lele dengan subtitusi tepung talas perlakuan A3 cukup tinggi sehingga dalam kerupuk ikan lele dengan subtitusi tepung talas banyak mengandung mineral yang cukup 
tinggi dan kandungan abu kerupuk ikan lele dengan subtitusi tepung talas pada perlakuan A1 dan A2 cukup rendah. Hal ini sesuai dengan pendapat Wiriano (1984) yang menyatakan bahwa semakin tinggi kadar abu pada suatu prodak maka semakin tinggi pula kandungan mineral pada produk tersebut sedangkan semakin rendah kadar abu pada suatu prodak maka semakin rendah kandungan mineral pada prodak tersebut, dan dengan tingginya mineral

dalam bahan pangan hal tersebut tidak dapat mempengaruhi nilai gizi pada produk tersebut.

\subsubsection{Uji Kemekaran}

Hasil analisis rata-rata uji kemekaran pada kerupuk ikan lele pada subtitusi tepung talas dengan tiga kali pengulangan analisa dengan hasil ditunjukan oleh Tabel 5 dan gambar 8 di bawah ini.

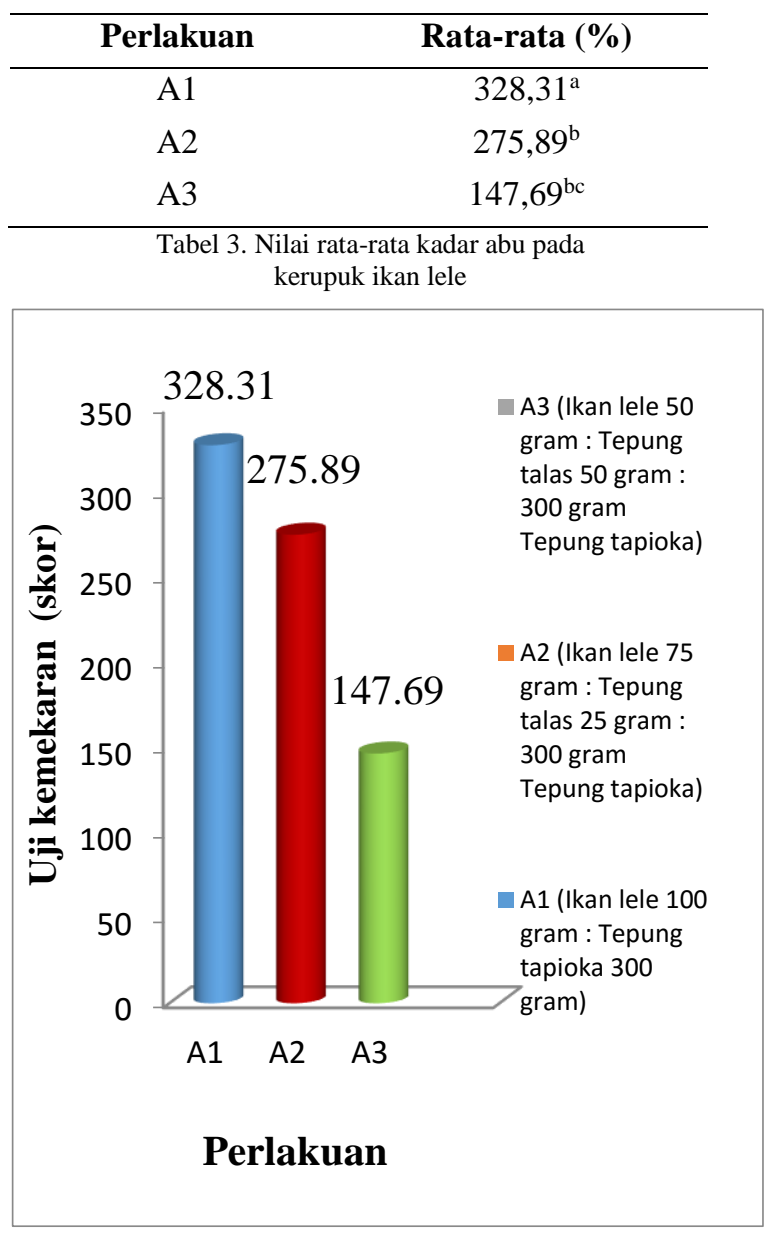

Gambar 9. Nilai rata - rata uji kemekaran kerupuk ikan lele

Berdasarkan gambar 9 di atas, nilai ratarata uji kemekaran pada kerupuk ikan lele dengan subtitusi tepung talas $\mathrm{F}_{\text {hitung }}$ (11.00) lebih besar dari $\mathrm{F}_{\text {tabel }}(0.05)$ yaitu (5.14) dan $\mathrm{F}_{\text {tabel }}(0.01)$ yaitu 10.92. Hasil analisis sidik ragam ini menunjukan bahwa kerupuk ikan lele dengan subtitusi tepung talas berbeda nyata terhadap kadar air pada ketiga perlakuan tersebut, sehingga dilakukan uji BNT lagi.

Dilihat dari tabel di atas, nilai rata-rata uji kemekaran yang terbaik dimiliki oleh perlakuan A1 yaitu $328.31 \%$, semakin mekar kerupuknya maka semakin baik produk tersebut, sedangkan nilai ratarata kadar air yang tertinggi dimiliki oleh perlakuan A3 yaitu $147.69 \%$. Hal ini disebabkan semakin banyak penambahan tepung talas pada setiap perlakuan akan berpengaruh pada nilai rata-rata. Hal ini sesuai dengan pernyatan Tahir (1985), bahwa kandungan amilopektin yang lebih tinggi dari bahan akan memberikan kecenderuangan pengembagan kerupuk yang lebih besar dibandingkan dengan amilosa yang tertinggi, amilosa cenderung memicu tingkat kemekaran kerupuk, sedangkan amilopektin berfungsi sebaliknya mengarah pada pembentukan tekstur yang lebih ringan yang berhubungan langsung dengan kemekaran kerupuk, dan pada tepung talas banyak mengandung amilopektin dibandingkan dengan amilosanya sehingga dapat menpercepaat proses pengembangan kerupuk dan bembentuk teksrut ysng lebih ringan dan lebih renyaah.

\section{KESIMPULAN}

Kesimpulan penelitian adalah hasil uji organoleptik pada pembuatan kerupuk ikan lele yang paling disukai oleh panelis adalah perlakuan A1 (dari segi rasa, warna, aroma, tekstur). Perlakuan pada pembuatan kerupuk ikan lele dengan subtitusi tepung tepung talas memiliki nilai rata-rata kadar air dan kadar abu adalah $3.29 \%$ dan $1.72 \%$.

\section{DAFTAR PUSTAKA}

Ade. 1994. Mencari primadona baru ikan air tawar. Majalah Agrobisnis. Surabaya. 
Andarwulan, N., Kusnandar, F., Herawati, D. 2011. Analisa Pangan. Dian Rakyat, Jakarta

Koesbandi, S. 1974. Pengaruh Kadar Air terhadap 'Kerapuhan" (Cripness) Kerupuk Udang. [karya ilmiah]. Bogor: Institut Pertanian Bogor, Departemen Perikanan, Fakultas Kedokteran Hewan dan Peternakan, Universitas Brawijaya. Afiliasi Fakultas Perikanan, Institut Pertanian Bogor.

Tababaka, T. 2004. Pemanfaatan tepung tulang ikan patin (Pangasius sp.) sebagai bahan tambahan kerupuk. [skripsi]. Bogor: Fakultas Perikanan dan Ilmu Kelautan, Institut Pertanian Bogor.

Tahir, S. 1985. Mempelajari Pembuatan Dan Karakteristik Kerupuk Dari Tepung Sagu (Metrixylon Sagu R). Skripsi. Jurusan Teknologi Pertanian. Fakultas Pertanian. Universitas Hasanudin, Ujung Pandang.

Winarno. F.G. 2008. Bahan Tambahan Makanan.Gramedia, Jakarta.

Winarno, F.G. 2002 Flavor Bagi Industri Pangan. Embrio Press. Bogor.

Wiriano, H. 1984. Mekanisasi dan Teknologi Pembuatan Kerupuk. Balai Besar Industri Hasil Pertanian. Bogor : Departemen Perindustrian.

Zaki. 2009. Budi Daya Ikan Lele ( Clarias batrachus).http://wilystara 2008

Biologi.com/journal/item/54/Budi Ikan Lele (Clariasbatrachus). (februari 2015).

Hartati, N.S dan Prana, T.K. 2003. Analisis kadar pati dan serat kasar tepung beberapa kultivar talas. Jurnal Natur Indonesia. 6(1): 29-33.

Yuliatmoko, W dan Satyatama, D.I. 2012. Pemanfaatn umbi talas sebagai bahan substitusi tepung terigu dalam pembuatan cookies yang disuplementasi dengan kacang hijau. Jurnal Matematika, Sains, dan Teknologi. 13 (2): 94-106. 